\title{
STRATEGI, AGEN, DAN POSISI EMHA AINUN NADJIB DI ARENA SASTRA DAN ARENA SOSIAL
}

\author{
Latief S. Nugraha \\ Balai Bahasa Provinsi Daerah Istimewa Yogyakarta \\ Email: harjomartono89@gmail.com
}

\begin{abstract}
Abstrak
Penelitian ini bertujuan untuk mengetahui posisi, peran dan strategi yang dilakukan oleh Emha Ainun Nadjib sebagai agen di arena sastra dan arena sosial. Untuk membahas persoalan tersebut, penelitian ini mendasarkan analisis pada teori sosiologi sastra Pierre Bourdieu. Dari penelitian ini diketahui bahwa Nadjib tidak dapat mencapai posisi mapan dengan hanya mengandalkan karya sastranya, namun lebih karena gerakan sosial dan politik yang dilakukan dalam pergulatannya di arena sastra dan arena sosial. Nadjib berhasil mengelola modal dengan strategi rekonvensi dan strategi reproduksi dalam rangka mengaplikasikan ide-idenya. Hal tersebut dilakukan untuk mengakumulasi modal dalam meraih, mempertahankan, serta meningkatkan pengakuan sosial dalam arena sastra nasional yang selanjutnya bertrajektori ke arena sosial yang lebih luas. Selebihnya, peran agen di sekelilingnya juga memiliki pengaruh besar dalam mengokohkan nama dan posisinya dalam konstelasi di arena sastra dan sosial, baik di Indonesia maupun di dunia internasional.
\end{abstract}

Kata kunci: Emha Ainun Nadjib, arena produksi kultural, agen, arena sastra, arena sosial.

\begin{abstract}
This research is conducted to prove about Emba Ainun Nadjib's position, strategies and employment as a agent in the literature and social field. This study uses the sociological literature theory proposed by Pierre Bourdieu to analyze the problems. The result of the study shows that Nadjib cannot achieve bis current position by relying only on his literary works, but also by relying on his social and political movements which are done in literature and social field. Nadjib successfully manages capital with reproduction strategy and reconvention strategy to apply his ideas. Those strategies are employed to accumulate capital for achieving, maintaining, and improving social recognition in the field of national literature which further creates trajectory to a wider social field. The rest, the role of agents around him also bave a major influence in cementing bis name and position in the constellation of literature and social field in both national and international.
\end{abstract}

Keywords: Emba Ainun Nadjib, the field of cultural production, agents, field of literature, field of social.

\section{Pendahuluan}

Seni budaya, termasuk sastra, di Yogyakarta sampai saat ini terus tumbuh dan berkembang beriringan dengan laju zaman. Salah satu hal yang menjadikan sastra di Yogyakarta dapat bertahan adalah adanya semangat kekeluargaan. Semangat kekeluargaan ini mewujud dalam bentuk sanggar atau komunitas. Banyak sanggar atau komunitas sastra di Yogyakarta yang telah dan tengah melahirkan sastrawan yang produktif dan kreatif.

Salah satu komunitas sastra di Yogyakarta yang melegenda adalah Persada Studi Klub (PSK). PSK merupakan salah satu komunitas sastra yang berpengaruh bagi perkembangan sastra Indonesia di Yogyakarta. Komunitas ini lahir tanggal 5 Maret 1969 (Santosa,2007) di kantor redaksi Mingguan Pelopor Yogya, Jl. Malioboro 175 A, yang diawaki oleh penyair Umbu Landu Paranggi, Teguh Ranusastra Asmara, Ragil Suwarna Pragolapati, Iman Budhi Santosa, Soeparno S. Adhy, Mugiyono Gitowarsono, dan M. Ipan Sugiyanto Sugito.

Emha Ainun Nadjib (selanjutnya disebut Nadjib) merupakan salah satu sastrawan yang berhasil setelah bergabung dengan PSK. Iklim sastra Yogyakarta tentu memiliki pengaruh penting bagi karier kesastrawanan Nadjib. Yogyakarta sebagai tempat bertemu dan berkumpulnya para sastrawan dari latar belakang yang berbeda-beda lantas menjadi sesuatu yang khas bagi Yogyakarta dan tidak dapat ditemukan 


\section{Jurnal Poetika Vol. III No. 2, Desember 2015}

di manapun di Indonesia. Di dalam sastra, ruang pengambilan posisi sastra ditentukan oleh serangkaian manifestasi terstruktur agenagen sosial yang terlibat di dalam arena sastra. Manifestasi tersebut meliputi karya-karya sastra, tindakan-tindakan politik, polemik-polemik yang dibangun, dan beberapa hal lainnya yang tidak bisa dipisahkan dari ruang posisi sastra yang ditentukan oleh kepemilikan modal (pengakuan) dalam jumlah tertentu sekaligus pendudukan posisi yang sudah kokoh di dalam struktur distribusi modal spesifik ini. Hal tersebut disebabkan oleh arena sastra yang tidak hanya sebagai arena kekuatan (a field of forces), tetapi juga arena pergulatan (a field of struggle) yang cenderung melanggengkan arena kekuatan ini (Bourdieu, 2012: 5). Hal tersebut dapat dipahami sebagai strategi-strategi yang menitikberatkan pada posisinya di dalam relasi-relasi kekuasaan (rapports de force) yang ada.

Dari segi kepenyairan, periode akhir1970an hingga akhir 1980-an dapat dikatakan sebagai periode pertama paling kreatif dan produktif bagi Nadjib. Di tahun-tahun tersebut ia banyak menerbitkan buku antologi puisi dengan berbagai kecenderungan, di antaranya puisi sosial (protes), sosio-religius, dan mistisisme Islam (tasawuf) (Alfian M., dkk., 2001: 118-119; Betts, 2006: 11). Beberapa prestasi Nadjib di masa itu antara lain memenangkan sayembara Tifa Sastra UI untuk kumpulan puisinya Sajak-sajak Sepanjang Jalan (1977), diundang membacakan puisi-puisinya di TIM (Alfian,2001:110), dan diundang dalam sejumlah program yang sifatnya internasional. Di antaranya adalah diundang dalam acara bidang teater Multi Cultural di Filipina (1980), The International Writing Program, Universitas Iowa, Amerika Serikat (1984), The International Songwriters Festival, Rotterdam, Belanda (1984), dan Festival Horizonte III di Berlin Barat, Jerman (1985) (Alfian,2001:110).

Bersama para penyair dan penyanyi Yogyakarta, salah satunya ialah Ebit G. Ade, Nadjib aktif menggelar acara Poetry Singing. Selain itu tercatat sejumlah komunitas kampus di
Yogyakarta dan beberapa artis ternama Indonesia membuat pertunjukan sastra dan teater. Bersama Teater Dinasti, Nadjib membuat pemanggungan puisi dan sejumlah naskah drama. Dengan diiringi seperangkat gamelan, Nadjib membacakan puisinya atau menyanyikannya bersama Grup Musik Dinasti, kemudian bersama Komunitas Pak Kanjeng, yang selanjutnya berkembang menjadi KiaiKanjeng sampai saat ini.

Pergulatan Nadjib di arena sosial tersebut tidak dapat dilepaskan dari arena kekuasaan Orde Baru. Arena kekuasaan Orde Baru memiliki kekuatan untuk memunculkan hegemonihegemoninya yang mendominasi. Pada saatitulah peluang berpolitik bagi Nadjib mulai terbuka, yang artinya akumulasi modal sosialnya semakin kuat. Hal tersebut karena selain bergulat di arena sastra dan seni, Nadjib mampu menembus dan meraih posisinya di arena agama, yang pada akhirnya mengarahkannya pada pergulatan di arena intelektual, politik, dan kebudayaan. Dengan gerakan kebudayaan tersebut hingga saat ini Nadjib memperoleh sekaligus mampu mempertahankan posisinya yang mapan serta memiliki pengikut (jamaah) yang banyak di kotakota besar hingga pelosok-pelosok Indonesia.

Keadaan tersebut membuat Nadjib tidak saja dikenal sebagai penyair, tetapi juga seorang esais/kolomnis, penulis naskah drama, penulis cerita pendek, pemusik, kiai, budayawan, dan sejumlah penamaan lain yang merujuk pada identitas yang multi talenta (Ariadinata, 2014: 621). Hal ini didukung oleh analisis Bourdieu yang secara meyakinkan menentang konsep-konsep esensial tentang seni dan visi-visi kharismatik seniman yang (masih) dominan hingga sekarang (Johnson, 2012: xi). Arena seni dan sastra harus dilepaskan dari dilema citra kharismatik seorang seniman yang melakukan aktivitas kesenian sebagai penciptaan murni dan nir-kepentingan. Selain itu, pendapat para reduksionis yang menganggap penjelasan tindakan produksi dan produksinya harus dilakukan menurut fungsifungsi eksternal sadar atau tak sadar mereka, dengan merujukkan fungsi-fungsi itu yang 


\section{Jurnal Poetika Vol. III No. 2, Desember 2015}

darinya patron-patron atau audiens diperoleh juga harus dihindari (Bourdieu, 2012: 11). Ideologi kharismatik dipandang sebagai dasar terdalam kepercayaan terhadap seni yang menjadi basis bagi berfungsinya arena produksi dan sirkulasi komoditas kultural. Meskipun demikian, Nadjib tidak dapat dilepaskan begitu saja dari arena sastra di Indonesia. Nadjib dipandang memiliki cukup peran dalam arena sastra di Indonesia, kendati setelah menjadi 'selebritis' ia tidak lagi banyak bergelut di dunia sastra (Jabrohim, 2003). Pergulatan-pergulatannya telah membawanya pada arena sosial yang besar. Ada banyak orang yang mampu menembus posisi sebagai sastrawan, tetapi tidak banyak yang mampu mempertahankannya sebaik Nadjib. Menariknya, hal tersebut justru tidak dilakukan Nadjib dengan menulis karya sastra.

Legitimasi yang dimilikinya dari berbagai arena membuat status sosial Nadjib semakin kuat dan berujung pada peraihan modal ekonomi yang juga besar. Saat ini Nadjib bahkan memiliki managemen yang terhimpun dalam Rumah Maiyah, dengan sekretariat di Jalan Wates Gang Barokah nomor 287, Kadipiro. Di sini pulalah aktivitas bersastra Nadjib bersama sastrawan eks-PSK berjalan dengan menerbitkan majalah sastra Sabana yang diambil dari nama rubrik sastra di mingguan Pelopor Yogya. Kini majalah Sabana telah bermetamorfosa menjadi "Majalah Maiyah" sebagai pendukung gerakan dan aktivitas dakwah kebudayaan Nadjib. Semua hal tersebut menunjukkan bahwa Nadjib telah menempati posisi yang mapan dan mampu bertahan, baik dalam arena sastra maupun arena sosial. Usaha mencapai, mempertahankan, dan memperbaiki posisi serta mendapatkan posisiposisi baru untuk membedakan dirinya dengan orang lain membutuhkan strategi. Perjuangan yang dilakukan adalah dengan pertarungan dalam arena sosial dan simbolis. Dalam menerapkan strategi diperlukan modal yang didukung oleh para agen. Hal tersebut terjadi karena strategi merupakan suatu praktik yang digunakan untuk mempertahankan kekuasaan atau melebarkan kekuasaan dalam suatu arena (Bourdieu, 1990: 61).

Bourdieu (1984: 125-131) membagi strategi menjadi dua macam, yakni 1) strategi reproduksi yang merupakan himpunan praktik yang dirancang oleh agen untuk mempertahankan atau meningkatkan modal ke arah masa depan, dan 2) strategi rekonvensi yang merupakan sejumlah pergerakan agen dalam ruang sosial yang terstruktur dalam dua dimensi, yakni keseluruhan jumlah modal dominan dan terdominasi.

Dalam konteks arena produksi kultural Nadjib, perubahan struktur-struktur sosial di arena membutuhkan ketepatan penerapan sarana dan strategi yang akan menentukan arah reproduksi sosial. Strategi-strategi tersebut musti digerakkan sesuai dengan modal dan habitus yang dimiliki di dalam arena dari waktu ke waktu mengingat strategi dapat berubah seiring dengan perubahan struktur sosial masyarakat. Hal inilah yang akan digali lebih dalam dalam penelitian ini.

\section{Strategi Nadjib dalam Meraih Posisi}

Nadjib memasuki arena sastra tentu bukan bertujuan untuk mendapat penilaianpenilaian yang buruk. Nadjib mandapatkan legitimasi dari berbagai pihak dengan terusmenerus menginvestasikan modal simbolik, modal sosial, modal kultural, dan modal ekonominya. Trajektori-trajektori yang dijalani Nadjib mengantarkannya pada posisi strategis sebagai sastrawan yang legitimit dengan segenap modal yang dimiliki tanpa harus masuk kembali ke dalam arena. Di arena sastra nasional, keberadaan Nadjib sebagai sastrawan telah dikenal luas dalam sejarah sastra di Indonesia tanpa harus menulis sastra. Hal tersebut karena Nadjib tidak hanya menempati posisi dengan masuk ke dalam arena melainkan juga menciptakan arena baru bagi dirinya.

Disampaikan oleh Bourdieu bahwa arena sastra dan seni sepanjang waktu adalah pergulatan antara dua prinsip hierarki, yakni prinsip heteronom dan otonom. Nadjib 


\section{Jurnal Poetika Vol. III No. 2, Desember 2015}

bergerak pada prinsip heteronom yang memandang seni sebagai arena ekonomis dan politis, sehingga ia sebagai orang yang ada di dalamnya memiliki dominasi tertentu seperti seni borjuis. Ia memiliki jumlah massa yang besar dan setia kepadanya. Meski demikian, pada awalnya ia sempat berada pada prinsip otonom, yang memandang seni untuk seni, dengan modal spesifik yang cenderung mengidentifikasi diri dengan tingkat independen dari ekonomi. Dapat dikatakan bahwa dalam arena sastra nasional Nadjib memiliki posisi strategis dalam kutub otonom dan kutub heteronom yang seimbang. Dari hal tersebut, dapat dilihat titik balik Nadjib sebagai strategi meraih posisinya, yakni (1) strategi rekonvensi dan (2) strategi reproduksi.

\section{Strategi Rekonvensi}

Eksplorasi estetika dalam karya banyak ditemui dalam karya-karya awal Nadjib. Hal tersebut terlihat dalam puisi-puisi yang ditulis Nadjib sepanjang tahun 1970-an. Ditengarai usia yang masih muda membuat banyak eksplorasi gaya ucap dan bentuk perpuisiannya.

Nadjib banyak menulis puisi-puisi cinta, eksistensi, dan protes sebagai upaya pencarian bentuk ucap demi meraih estetika sebuah karya pada awal karier kesastrawanannya. Pada masa ini, Nadjib belum memadukan wacana dalam bersastra dengan wacana di luar sastra. Nadjib masih mematuhi gaya tradisi perpuisian saat itu demi meraih modal simbolik sebagai penyair. Sebagai langkah awal, Nadjib mengikuti perpuisian penyair mapan dengan harapan puisinya lolos dalam rubrik "Sabana" sebagai rubrik elit mingguan Pelopor Yogya yang memuat karya-karya sastrawan yang sudah mapan.

Eksplorasi perpuisian gaya penyair terdahulu dalam karya-karya Nadjib dapat dilihat dalam kumpulan puisi awal Nadjib, yakni " $M$ " Fristasi (1975), Sajak-sajak Cinta (1978), dan Sajak-sajak Sepanjang Jalan (1978). Puisi-puisi dengan nuansa sosial-religius sudah mulai ada namun belum dominan. Pada masa selanjutnya, Nadjib memberikan alasan bahwa hal tersebut merupakan tahapan ketika ia berorientasi pada sastra murni atau sastra steril (dalam Alfian M., dkk., 2001: 113). Sastra steril maksudnya adalah tahapan manakala karya sastra masih menekankan kemurnian aspek estetika. Dapat dikatakan pada tahap itu, puisi-puisi Nadjib masih bertujuan sebagai kreativitas seni untuk seni, belum ada kepentingan-kepentingan politis di dalamnya.

Namun, sebagaimana diketahui pemikiran tersebut dimunculkan Nadjib jauh setelah proses produksi kultural karya-karya awal Nadjib berlalu. Artinya, ketika Nadjib menjalani proses yang dikatakannya sebagai tahap aktivitas seni untuk seni, saat itu ia justru belum memiliki gagasan konsep tersebut. Melalui strategi ini, Nadjib berhasil masuk ke dalam arena sastra dan meraih posisinya sebagai penyair garda depan Yogyakarta.

Dalam proses selanjutnya, banyak puisi yang ditulis Nadjib dengan memasukkan unsurunsur sosial dan religius. Selain itu, ia banyak menulis esai ke hampir seluruh media massa di Indonesia. Esai-esainya tergolong liar namun masuk akal dengan mengedepankan kritik sosial dalam pengertian luas, masalah keagamaan, masalah politik, dan masalah seni budaya. Hal ini membuat posisinya sebagai penyair dan penulis andal di Indonesia semakin kokoh dan besar.

Dalam pergulatan di arena sastra, Nadjib banyak mengaplikasikan ide-ide dalam beragam konsep mengenai sastra, lebih luas lagi mengenai persoalan kebudayaan, sosial, politik, dan keagamaan di Indonesia secara 'liar'. Salah satu pergerakan Nadjib dalam ruang sosial sastra adalah munculnya gagasan mengenai sastra independen yang mewarnai perdebatan sastra kontekstual yang dipelopori oleh Arief Budiman. Sastra independen dimaksudkan sebagai kemerdekaan kreatif seorang sastrawan. Nadjib beranggapan bahwa selama ini kemerdekaan kreatif diasosiasikan sebagai perlawanan terhadap kekuatan dari luar kesusastraan dengan pandangan seberapa jauh kondisi personal sastrawan merdeka dari latar belakang yang 


\section{Jurnal Poetika Vol. III No. 2, Desember 2015}

membentuk dan mengondisikannya. Lebih dalam adalah bagaimana sastrawan mampu melihat, memahami, dan menguasai latar belakang itu dalam dirinya, agar permunculan kreativitas sesuai dengan kemerdekaan manusiawinya sendiri secara otentik.

Nadjib menolak standardisasi (universalisasi), dikotomi, dan elitisasi kesenian kaitannya dengan term pemasyarakatan sastra sebagai arus balik. Nadjib mulai menyadarai usaha-usaha perpuisian, lewat berbagai modus yang sengaja maupun tidak, tetap memiliki kaitan dengan kehidupan di sekitarnya. Pada tahun 1980-an, pandangan mengenai seni untuk seni mulai bergeser ke arah dunia yang lebih luas di luar sastra. Berdasarkan refleksinya, konsep berpikir Nadjib mengenai sastra mengalami titik balik dari yang semula "sastra murni" beralih ke "sastra yang membebaskan".

Konsep sastra yang membebaskan dilengkapi dengan sentuhan aspek kesenian yang lebih luas dan kompleks. Hal tersebut merupakan sebuah usaha untuk "terus mencoba budaya tanding" terhadap penyempitan pemahaman yang sempit terhadap sastra. Menurut Nadjib, seharusnya puisi dapat digunakan oleh penyair untuk memperjuangkan kebebasan dari belenggu kekuasaan. Secara garis besar, dapat disimpulkan bahwa ide-ide dan praktik-praktik produksi sastra Nadjib mengarah pada usaha untuk 'bebas'.

Kecenderungan puisi Nadjib mengenai puisi sosial (protes), sosio-religius, dan mistisisme Islam (sufistik) lebih menonjol dilakukan sebagai trajektori. Semangat sastra dan semangat dakwah agaknya menjadi dasar berpikir dalam meraih sukses di dalam ruang struktur yang bisa mengalami pergantian dan distorsi. Hal tersebut terus berkembang seiring dengan produksi dan reproduksi karya yang dilakukan Nadjib. Dengan demikian, jenis modal yang didapat akan semakin beragam dan semakin kuat.

\section{Strategi Reproduksi}

Pada beberapa tahun pertama aktivitas
Nadjib, ia belum mengalami benturan dengan situasi politik nasional, karena tahun 19691975 konsentrasi terletak pada penulisan sastra, terutama puisi dan cerpen. Barulah di tahuntahun setelahnya Nadjib muncul "terutama bukan sebagai sastrawan", melainkan "makhluk sosial" (Rahardjo, 2006: xxiii). Dapat dilihat bahwa titik balik yang dilakukan Nadjib dalam berkarya adalah dengan memasukkan segala unsur masalah kehidupan dalam karya-karyanya.

Melalui strategi reproduksi sebagai praktik-praktik kesenian dari arena sastra ke arena sosial, Nadjib banyak mengolah gagasangagasan religiusitas, kesenian, kebudayaan, sosial, politik, bersamaan dengan mendayagunakan konsep kerja bersastra. Strategi reproduksi ini diawali dengan aksi baca puisi di sejumlah kesempatan. Hal tersebut kemudian berkembang menjadi sebuah pertunjukan dengan diiringi instrumen musik gamelan dan dinyanyikan. Hal ini terbukti mendapat perhatian dari beragam segmen penonton di masyarakat sosial yang luas.

Nadjib menggunakan sastra untuk masuk ke dalam bentuk kesenian yang beragam dan komprehensif dalam masalah kebudayaan. Sejak pertengahan tahun 1980-an dan terutama pada tahun 1990-an, Nadjib melakukan perpindahan dalam jalur sastra. Dari dunia penulisan Nadjib berpindah ke dunia pertunjukan. Perpindahan yang dilakukan Nadjib lebih mengarah pada komunikasi berbagai gagasan pemikirannya. Gagasan tentang kesenian dan dinamika dunia politik banyak diaktualisasikan di hadapan masyarakat.

Lebih luas lagi, Nadjib mencoba menyiasati media untuk sosialisasi pikiranpikirannya. Sebagaimana diketahui bahwa Nadjib memulai pergulatannya dalam arena dengan menulis puisi, cerpen, dan esai/kolom. Dalam hal ini, Nadjib sangat mengandalkan media massa koran dan majalah. Audiens media ini tentu terbatas besarnya mengingat budaya baca masyarakat masih tergolong rendah. Kemudian Nadjib bergerak dalam dunia lisan melalui seminar, diskusi, ceramah, dan teater. 
Hal ini menunjukan bahwa Nadjib memiliki ruang audiens yang bertambah dan beragam.

Meskipun demikian, telah disadari bahwa setiap media memiliki keterbatasan dan kelebihan serta dampak yang ditimbulkan. Dari situ Nadjib memanfaatkan media audio dan audio visual. Media radio dan televisi pun dimasuki Nadjib untuk memperluas jaringannya. Radio dan televisi sebagai budaya massa berkaitan dengan kapitalisme mampu dinetralisasi oleh Nadjib. Cara ini terbilang sukses, mengingat tidak semua sastrawan dapat melakukannya.

Logika-logika dalam pengetahuan sastra yang dimiliki Nadjib banyak digunakannya untuk menyelesaikan persoalan dan pertanyaanpertanyaan yang dibahas dalam acara-acara dakwah dan dialog budayanya bersama Maiyah. Latar belakang sosial dan religi di masa kecilnya dipadukan dengan sastra menghasilkan pola pikir yang liar namun masuk akal. Pemikiranpemikiran Nadjib yang multi-dekonstruksi membuatnya disebut "kiai mbeling" oleh banyak kalangan.

Strategi reproduksi yang dilakukan Nadjib mengarah pada pertahanan dan peningkatan modal simbolik dan modal ekonomi. Pertahanan dan peningkatan modal simbolik dijalankan sebagai upaya untuk mempertahankan dan meningkatkan pengakuan sosial ke arah masa depan. Posisi Nadjib di arena sastra dan sosial diharapkan akan tetap kokoh dan abadi. Demikian halnya dengan pertahanan dan peningkatan modal ekonomi. Modal-modal tersebut digunakan Nadjib untuk melanggengkan hubungan-hubungan sosial yang dapat dipergunakan dalam jangka pendek maupun jangka panjang.

\section{Peran Agen dalam Mengukuhkan Posisi Nadjib}

Di dalam arena, Nadjib memiliki sejumlah agen dominan dengan pengetahuan dan pengalaman terhadapnya, baik secara komunitas maupun secara individu. Peran agen Nadjib dalam arena berposisi dan terlibat dalam kompetensi yang mengontrol kepentingan atau sumber daya yang khas dalam arena bersangkutan. Kemampuan agen-agen Nadjib terkait dengan relasinya terhadap struktur sosial yang melalui praksis dan interaksi antara mereka di lingkungannya membuat keberadaan Nadjib semakin kokoh. Kedudukan para agen dalam arena memiliki kekuatan dalam memberikan penilaian dan legitimasi tertentu kepada Nadjib. Berikut ini dijelaskan beberapa agen dan perannya terhadap Nadjib.

\section{Restu dari "Presiden Malioboro"}

Kekuasaan tunggal Paranggi sebagai pengasuh rubrik sastra "Sabana" dan "Persada" di mingguan Pelopor Yogya juga dalam PSK memiliki kekuatan untuk memberikan legitimasinya kepada Nadjib sebagai penyair di usianya yang masih 16 tahun. Status penyair dinilai oleh masyarakat sebagai status yang tinggi dalam arena sastra. Modal simbolik dan kharisma yang dimiliki Paranggi membuat banyak seniman Yogyakarta, termasuk Nadjib dan anggota PSK, segan padanya. Modal Paranggi tersebut secara tidak langsung telah dibagikan kepada anggota PSK. Nadjib adalah salah satu yang mampu mengolah warisan modal dari Paranggi semenjak di PSK hingga kini.

Intensitas Nadjib di PSK membuatnya dekat dengan Paranggi. Kedekatan Nadjib dengan Paranggi diibaratkannya sebagaimana Arjuna terlalu dekat dengan Pendeta Durna (2013: ix). Tidak menutup kemungkinan jika dari kedekatan tersebut, Paranggi menyadari adanya bakat Nadjib selain menulis puisi, yakni menulis esai. Nadjib pertama kali menulis esai atas permintaan Paranggi untuk menjadi pembicara diskusi PSK bersama Rachmat Djoko Pradopo. Kendati acara tersebut gagal digelar disebabkan gedung yang sedianya akan digunakan sebagai tempat acara tidak pernah dihubungi oleh Paranggi, namun justru dari situlah bakat Nadjib dalam penulisan esai/makalah dapat diperlihatkan. Kelak hal tersebut menjadi salah satu modal Nadjib dalam dunia kepenulisan. 
Menurut Paranggi, hanya ada tiga orang sastrawan yang ditemukannya selama di PSK (Astika,2013). Tiga orang itu adalah Iman Budhi Santosa, Darwis Khudori, dan Emha Ainun Nadjib. Hal tersebut dapat dikatakan sebagai "restu" dari "sang guru" kepada "muridnya", terutama bagi Nadjib, mengingat pada saat bergabung dengan PSK ia masih remaja. Saat ini Nadjib dipandang sebagai anggota PSK yang paling sukses di antara anggota lainnya. Lebih dari itu, Nadjib menyatakan bahwa yang dipelajarinya dari Paranggi bukanlah persoalan penulisan puisi yang kemudian membuat dirinya menjadi penyair, melainkan bagaimana menjalani "kehidupan puisi" (Kompas, 2012).

\section{Nadjib Anak Angkat Umar Kayam}

Umar Kayam merupakan salah seorang budayawan ternama di Indonesia. Jaringannya yang luas membuat perannya dalam arena sastra Indonesia terutama di Yogyakarta menjadi penting. Oleh sebab itu, PSK acap kali membuat aktivitas dialog sastra bersama Kayam dan sastrawan lainnya yang dipandang telah mapan di arena sastra nasional. Dari hal tersebut modal simbolik yang dimiliki Kayam terserap oleh anggota-anggota PSK. Nadjib dan Suryadi Ag. adalah dua nama sastrawan Yogyakarta yang dikenal memiliki kedekatan dengan Kayam. Bahkan dalam suatu kesempatan pada acara Bincang-Bincang Sastra Studio Pertunjukan Sastra "Launcing Empat Kumpulan Puisi Mustofa W. Hasyim", di Ruang Seminar Taman Budaya Yogyakarta, Sabtu 23 Februari 2013 Nadjib mengakui bahwa dirinya dan Suryadi telah dijadikan anak angkat oleh Kayam.

Modal simbolik yang dimiliki Kayam di arena sastra nasional berpengaruh dalam karier Nadjib dan Suryadi. Sebagai agen, arena berposisi dan keterlibatan Kayam dengan kompetensi yang dimiliki mampu memberikan kontrol terhadap sumber daya khas Nadjib dalam arena. Imam Budhi Santosa dalam wawancara mengindikasikan dampak dari peranan Kayam tersebut dengan merekomendasikan Nadjib dalam kegiatan kesenian International Writing Program di Universitas Iowa, Iowa City, Amerika Serikat tahun 1981. Kepercayaan yang sama juga diberikan kepada Suryadi tahun 1982.

Kompetisi di antara keduanya melaju, terutama setelah Suryadi pada akhir tahun 70an melahirkan prosa lirik Pengakuan Pariyem, yang secara resmi dicetak pada awal tahun 80-an. Dalam dari itu, prosa lirik Pengakuan Pariyem dipersembahkan Suryadi untuk Kayam. Karya Suryadi mendapat dukungan dari dunia akademik, terutama UGM. Disampaikan oleh Halim H.D. (1995: xv) bahwa Nadjib dan Suryadi mendapatkan perlakuan yang berbeda dari Kayam dan Ashadi Siregar. Suryadi lebih dipilih karena "dengkulnya lentur", sedangkan Nadjib sosoknya "bisa melotot, bibir berkerut, dan mendenguskan napasnya." Halim H.D. menambahkan bahwa Paranggi, Kayam, dan Siregar berharap dari peristiwa itu kreativitas Nadjib bisa terus terjaga.

Selain itu, keterlibatan Kayam dalam sejumlah acara kebudayaan yang sifatnya nasional acapkali melibatkan Nadjib sebagai salah satu wakil dari penyair muda. Dalam acara Kongres Kebudayaan Nasional IV tahun 1991 misalnya, Kayam berkedudukan sebagai panitia pengarah, sehingga memiliki kekuasaan atas rekomendasi-rekomendasinya. Alih-alih panitia mempertimbangkan sejumlah kasus pencekalan terhadap Nadjib di sejumlah kota besar, posisi Nadjib ‘tergantikan' Nirwan Dewanto, hal ini kemudian menjadi berita di media massa Berita Buana 1 November 1991 pada saat itu dengan judul "Kongres Kebudayaan Nasional IV, Kontroversi Dibalik Tampilnya Penyair Muda Nirwan Dewanto", padahal modal simbolis yang didapatkan dari acara tersebut penting bagi karier kepenyairan Nadjib.

\section{Ashadi Siregar Pendiri Institusi Budaya Bernama Nadjib}

Di dalam arena sastra Yogyakarta, Ashadi Siregar cukup disegani oleh para sastrawan hingga saat ini. Hal tersebut tidak terkecuali oleh 
sastrawan-sastrawan Yogyakarta yang dihasilkan oleh PSK. Siregar memiliki kedekatan dengan Paranggi, tetapi tidak sepenuhnya tahu aktivitas PSK. Meskipun demikian, Siregar diketahui dekat dengan sejumlah anggota PSK, di antaranya adalah Suryadi dan Nadjib. Hal tersebut ditunjukkan dengan prolognya "Pemaknaan Terhadap Dinamika Kreatif Yogyakarta era '60-'70an' dalam buku Orang-orang Malioboro, epilognya "Linus yang Saya Kenal" dalam Pengakuan Pariyem, dan "Liberalisasi Pendidikan Alam" dalam Jalan Sunyi Emba.

Dalam komentar pendeknya di Jalan Sunyi Emba tersebut, Siregar menyatakan bahwa Nadjib mengalami liberalisasi oleh alam dan bermetamorfosa dari suatu individu menjadi suatu institusi yang signifikan di tengah kehidupan. Sesuai pandangan Bourdieu, bahwa seseorang dapat membentuk institusi ketika dia memiliki kekuatan. Nadjib berani hadir sebagai individu yang bebas, keluar dari komunalisme dalam lingkup agama, ideologi, textbook, atau ikatan-ikatan yang membelenggunya. Menurutnya, Nadjib memiliki bakat otentik yang "menyelamatkannya" dari "dosa-dosa" dunia sekolah. Sebagai suatu institusi, Nadjib jauh lebih berarti dibanding ribuan bahkan laksaan lulusan dunia sekolahan (2006: 1).

Membaca wacana Nadjib adalah sebagaimana menghadapi institusi budaya yang terbebas dari regulasi kepentingan pragmatis. Hal itu menjadi sesuatu yang langka di tengahtengah pertarungan dan perebutan hegemoni untuk kepentingan kelompok komunal (2006: 1). Dari komentar tentang Nadjib itu, Siregar mempertanyakan, "apakah masyarakat lebih mendapat kemanfaatan dari Nadjib andaikata ia bergelar sarjana ekonomi, atau sebagaimana Nadjib yang dikenal sekarang?"

Pernyataan-pernyataan tersebut menunjukkan legitimasinya terhadap Nadjib sebagai contoh manusia yang sukses secara intelektualitas melalui liberalitas pendidikan alam. Berkaitan dengan PSK, Siregar berusaha mengunggulkan Nadjib sebagai murid
Paranggi-temannya semasa kuliah di Fakultas Sosial dan Politik UGM dan sesama redaktur media massa-dibanding anggota PSK yang lain. Dengan menyatakan bahwa Nadjib telah bermetamorfosis dari suatu individu menjadi suatu institusi, itu berarti telah membuat dan menjaga posisi mapan Nadjib sebagai "anugerah alam bagi manusia Indonesia." (Siregar, 2007) Siregar memiliki modal sebagai kekuatan untuk menjadi agen Nadjib dengan memberikan legitimasi-legitimasinya. Dalam hal ini, dapat dilihat bahwa Siregar sebagai seorang agen lebih memberikan penilaian kepada sosok Nadjib ketimbang kepada karya-karya yang dihasilkan Nadjib.

\section{Menimbang Peran TIM}

Taman Ismail Marzuki (TIM) digagas sebagai wadah bagi apresiasi karya seni dan sastra. Sebagaimana telah dijelaskan sebelumnya, TIM merupakan tempat para seniman dan sastrawan berkumpul serta menunjukkan hasil karyanya. Hal tersebut didukung dengan hadirnya Dewan Kesenian Jakarta (DKJ) sebagai sebuah organisasi bagi para seniman dan sastrawan.

Sayangnya, keberadaan TIM dan DKJ berdampak pada terpusatnya perhatian dan kegiatan kesenian di Jakarta sebagai Ibukota Indonesia (Teeuw, 1989: 60). Salah satunya adalah acara Pesta Puisi yang digelar oleh DKJ. Acara tersebut melibatkan penyair-penyair muda dari seluruh Indonesia. Hal ini membuat Jakarta dianggap mewakili arena sastra nasional dan mampu memberi legitimasi yang tinggi.

DKJ pada tahun 1974 mengundang Nadjib dan Suryadi untuk tampil dalam acara Pesta Puisi 1975 sebagai perwakilan Yogyakarta. Ada 40 penyair muda dari seluruh Indonesia yang diundang dalam acara ini. Dalam acara tersebut Nadjib diminta untuk bicara dengan tema "Apa Mau Emha dengan Puisi Indonesia". Hal ini menyusul perdebatan panjang Nadjib dengan Goenawan Mohamad di Kompas.

Perdebatannya dengan Mohamad di Kompas berhasil menguatkan modal simbolik 


\section{Jurnal Poetika Vol. III No. 2, Desember 2015}

Nadjib dalam konstelasi arena sastra nasional. Polemik yang terjadi antara Nadjib dan Mohamad justru semakin memperkuat modal simbolik Nadjib. Dengan berpolemik melawan sastrawan yang sudah mapan, posisi Nadjib sebagai seorang sastrawan muda terangkat dalam arena sastra nasional. Diundangnya Nadjib di TIM serta diadakannya acara khusus untuk "membantai" Nadjib menunjukkan banyaknya modal yang diraih Nadjib akibat polemik tersebut. Dengan itu, popularitas yang didapat Nadjib menjadi semakin luas. Perdebatannya dengan Mohamad kelak akan membuat Nadjib dipercaya untuk menulis kolom di Tempo.

Modal simbolik Nadjib di arena sastra nasional dari tahun ke tahun berangsur membesar. Tulisan-tulisannya berupa puisi dan esai bertebaran di media massa nasional. Selain itu, ia juga menulis naskah sandiwara untuk dipentaskan bersama Teater Dinasti di berbagai kesempatan. Tidak mengherankan jika pada tahun 1983 modal Nadjib juga Suryadi telah semakin kuat sebagai sastrawan. Pada tahun tersebut, Nadjib dan Suryadi sudah memiliki kekuatan untuk menolak undangan acara Pesta Puisi seperti yang digelar di tahun-tahun sebelumnya.

Pengkategorian penyair yang dirasa timpang dan tidak proporsional membuat Nadjib enggan hadir memenuhi undangan. Dalam pernyataannya disampaikan posisi Hamid Jabar, Adri Darmaji, Suryadi dan dirinya dinilai sudah bukan penyair muda lagi, sehingga ia menolak ketika diminta untuk baca puisi rombongan. Nadjib menolak persepsi birokrasi pengurus kesenian pusat mengenai penyair. Seperti apa yang tertuang dalam "Dua Penyair Terkemuka Tolak Baca Puisi di TIM”, Kedaulatan Rakyat, Rabu Kliwon, 26 Oktober 1983, Nadjib berpesan kepada penyair muda Yogyakarta bahwa "siapapun tidak usah silau pada Jakarta. Kita tidak usah menjadi korban psikologi feodalistik yang melihat acara di TIM sebagai puncak. Untuk mewakili Yogya, siapapun tidak wajib datang ke Jakarta. Yogya cukup sibuk dengan kegiatannya sendiri, dan ini lebih berarti daripada satu dua orang wakil harus berangkat ke Jakarta. Jakarta bukan barometer. Kita layak intens dengan Yogya, tapi santai saja dengan Jakarta."

Tampak bahwa mulai ada perlawanan menolak keterpusatan perhatian atas kegiatan seni yang digelar di Jakarta oleh Nadjib dan sastrawan Yogyakarta. Disadari bahwa ruang kemungkinan bagi penulis untuk meraih legitimasi sastra dari pusat hanya akan tercipta jika mereka taat kepada pusat. Penolakan yang dilakukan Nadjib kepada TIM justru membuat posisinya sebagai sastrawan yang idealis dalam pandangan masyarakat menjadi semakin kuat. Mengingat TIM dalam pandangan masyarakat merupakan representasi gengsi terhadap legitimasi arena sastra nasional.

\section{Horison, Kompas, Tempo, DeTiK}

Keberadaan kritikus dan sastrawan mapan di Jakarta membuat sastrawan daerah berkompetisi dengan mengirimkan karyanya ke pusat. Selain itu, banyak media massa terbit di Jakarta, termasuk di dalamnya adalah media massa yang memuat berita dan karya sastra. Karya sastra yang dimuat di media massa Jakarta dianggap telah mendapat pengakuan dari arena sastra nasional.

Hal tersebut adalah salah satu yang membuat popularitas Nadjib di arena sastra nasional melejit. Tulisan Nadjib berupa puisi, cerpen, dan terutama esai atau kolom Nadjib yang tergolong lebih kuat dibanding dengan tulisan lainnya, banyak bertebaran di media massa pusat. Sebagaimana telah disinggung dalam bab sebelumnya, Nadjib sudah menulis esai di Kompas pada tahun 1977-1978 ketika umurnya baru seputar 24 atau 25 . Ia telah menulis kolomsecara berlangganan-untuk majalah Tempo pada tahun 1981 ketika Nadjib masih berumur 28 tahun. Diperkirakan waktu itu ia termasuk penulis paling muda yang menembus Kompas atau Tempo yang dikenal sangat selektif tersebut. Tulisan-tulisannya kemudian dikumpulkan 
menjadi banyak buku yang laris di pasaran. Hal tersebut tidak lepas dari dukungan Jakob Oetama sebagai pemimpin umum Kompas dan Goenawan Mohamad sebagai pemimpin redaksi majalah Tempo.

Seperti yang sudah disinggung sebelumnya, Horison merupakan majalah sastra kanon yang mampu memberikan legitimasi kuat kepada sastrawan. Hal ini didukung oleh para redaktur majalah tersebut yang terdiri dari sastrawan dan kritikus sastra yang sudah memiliki posisi mapan di arena sastra nasional, seperti Mochtar Lubis, Ali Audah, Arief Budiman, Fuad Hassan, Goenawan Mohamad, M.T. Zen, P.K. Ojong, Umar Kayam, Sapardi Djoko Damono, H.B. Jassin, Taufiq Ismail, dan Sutardji Calzoum Bachri. Banyak karya Nadjib yang juga dimuat oleh majalah sastra yang hingga kini masih bertahan ini. Nama-nama tersebut setidaknya sampai tahun 1980-an masih bertahan di Horison sebelum akhirnya terbelah-belah. Legitimasi dari banyaknya sastrawan dan kritikus sastra ternama selaku redaktur majalah sastra bergengsi tersebut sudah tentu memperbesar modal simbolik Nadjib sebagai sastrawan di arena sastra nasional. Selain itu, pada tahun 1993-1994 Nadjib banyak menulis "opini plesetan" di tabloid DeTik, tabloid berita politik yang didirikan Eros Djarot, bersama aktivis-aktivis mahasiswa dari berbagai kampus di Indonesia, seperti Universitas Nasional Jakarta, UGM, dll. Tabloid ini bersama majalah mingguan Tempo dan majalah Editor, pada tanggal 21 Juni 1994 dibredel oleh rezim totaliter Soeharto. "Opini plesetan" ini kemudian dibukukan dengan judul yang sama yakni OPLeS yang diterbitkan oleh Penerbit Mizan. Di dalam pengantar buku tersebut Djarot menyatakan bahwa pada saat menulis OPLeS bagi pembaca DeTiK, Nadjib mencoba memuliakan sidang pembaca yang disadari sebagai pemegang kedaulatan (rakyat) di Indonesia agar tetap berpikir merdeka. OPLeS menjadi penting karena tindak terhadap Tempo, DeTiK, Editor berhasil menggiring media massa ke ruang yang gagap menangkap realita kehidupan dan gugup menyuarakan kebenaran nuraninya (1995: 7).

Legitimasi dari sejumlah nama tokoh di sejumlah media massa ternama di Indonesia membuat akumulasi modal simbolik Nadjib sebagai sastrawan semakin besar dan kokoh. Hal ini senada dengan apa yang telah disampaikan Goenawan Mohamad dalam tulisannya yang ditolak oleh majalah Forum sebagai tanggapan tulisan Nadjib di majalah yang sama, yakni "Indonesia di Antara Rendra dan Goenawan." Mohamad menyatakan, "Dalam abad media massa, tokoh bahkan kian mendesak pokok. Orang tenar telah jadi komoditi laris. Di Indonesia tendensi ini kian kuat karena semakin kuat komodifikasi informasi. Tapi juga karena kehidupan kian didominasi oleh politik yang tidak melibatkan orang banyak: politik hanya keributan sejumlah VIP, dan massa hanya dianggap mengapung, seperti bangkai." (http://www. library.ohiou.edu/indopubs/1996/01/01/0021. html)

\section{Ian L. Betts Meramaikan (dengan) Jalan Sunyi Emha}

Pertemuan Ian Leonard Betts dengan Nadjib di bulan Mei 1998 untuk pertama kalinya menghasilkan sebuah buku tentang Nadjib yang juga menjadi rujukan penting bagi penelitian ini. Buku Jalan Sunyi Emba diterbitkan pertama kali dalam bahasa Inggris dengan judul The Silent Pilgrimage: Emba Ainun Nadjib, A Lifelong Journey of Faith. Hal ini memungkinkan pergulatan Nadjib selama ini dapat dikenal luas hingga internasional. Lebih dari itu, Betts yang berasal dari London, Inggris secara aktif memberi bantuan kepada Nadjib dan KiaiKanjeng untuk urusan-urusan luar negeri.

Betts menyatakan bahwa melalui buku tersebut ia berupaya menyajikan kepada pembaca berbahasa Inggris sebuah karya anak bangsa dari negeri yang seni dan budayanya masih belum banyak dikenal di luar batas-batas negeri tersebut. Menurutnya, Nadjib telah memberikan sumbangan unik kepada lanskap 


\section{Jurnal Poetika Vol. III No. 2, Desember 2015}

gerakan budaya modern Indonesia, namun di negerinya sendiri Nadjib justru tidak tercatat. Betts menyayangkan terabaikannya wacana sosial yang dilakukan Nadjib di Indonesia, sehingga mendapat penilaian terlalu rendah. Dalam dari itu, Betts mempertanyakan mengapa volume karya Nadjib yang begitu besar hanya mendapat tempat di pinggiran (Betts,2006). Betts menambahkan, bahwa dalam bidang agama Nadjib adalah seorang tokoh Islam yang dicintai massa, yang dianggap sebagai wali, tetapi masih berani mengatakan dirinya adalah seorang pluralis. Nadjib bekerja keras membantu kelompok-kelompok yang disingkirkan atau dipersulit dalam soal agama (SINDO, 2006).

Buku Betts mengenai Nadjib semakin meneguhkan bahwa sekian banyak aktivitas Nadjib tersebut, dengan tidak berada di jalur mainstream, merupakan sebuah usaha pemeliharaan modal simbolis yang dimilikinya. Dalam halaman khusus buku tersebut juga terdapat sejumlah komentar dari banyak orang, mulai orang biasa hingga tokoh-tokoh ternama di Indonesia dan luar negeri. Tulisan mengenai kunjungannya ke hampir seluruh provinsi di Indonesia, ratusan kabupaten, ribuan kecamatan dan desa di pelosok Nusantara menunjukkan bahwa Nadjib semakin populer dalam arena sosial. Undangan-undangan kepada Nadjib dan KiaiKanjeng untuk tur ke luar negeri yang disampaikan oleh Betts menunjukkan jangkauan aktivitas Nadjib yang sudah mencapai dunia Internasional. Kini Nadjib telah menjadi figur yang ditokohkan oleh banyak kalangan baik di dalam maupun luar negeri setelah menempuh "jalan sunyi" yang sesungguhnya dipenuhi dengan "kehebohan-kehebohan".

\section{Peraihan Posisi Nadjib dalam Arena Sastra dan Arena Sosial}

Citra kesuksesan dan status sosial kesastrawanan Nadjib ditunjukkan dengan peraihan posisi dalam arena sastra dan arena sosial saat ini. Dalam pergulatannya dapat dikatakan bahwa Nadjib memperoleh kekuasaan yang dinamis dan memiliki beragam potensi untuk eksis. Perjuangan memperebutkan posisi kesastrawanan yang bermula di PSK dipertahankan sebagai modal tertentu dalam meraih posisi di arena selanjutnya.

Melalui puisi, struktur kognitif Nadjib sebagai penyair masuk ke dalam realitas sosial dalam arena apapun. Nadjib sebagai penyair mampu mengorganisasikan prinsip-prinsip yang kemudian melahirkan praktik-praktik di masyarakat. Di dalam ruang sosialnya, Nadjib mampu membesarkan yang kecildan mengecilkan yang besar. Hal tersebut menghasilkan tindakantindakan sesuai dengan arena dan modal yang dimilikinya.

Berkatmobilitasyang dikerjakan Nadjibdi berbagai arena, khususnya arena sastra, akumulasi secara prestise, status, otoritas, dan legitimasi telah diraih olehnya. Hal tersebut tergolong sebagai modal simbolis Nadjib yang menjadi salah satu manifestasi dalam pergulatannya selama ini. Di samping itu, dapat dikatakan bahwa bidang agama merupakan hal yang pertama digeluti Nadjib semasa kecil bersama keluarganya yang dilanjutkan di pesantren. Jika dibandingkan dengan teman-temannya di PSK, tentu Nadjib adalah penyair yang lebih paham soal agama dan bisa mendayagunakan hal itu di dalam karyakaryanya. Dapat dilihat bahwa sejak awal Nadjib sudah menggunakan tema-tema religi di dalam karya-karyanya, baru kemudian disusul dengan karya-karya yang sifatnya sosial. Dalam dari itu, Nadjib banyak memadukan antara tema religi dan sosial dalam karya-karyanya. Nadjib selanjutnya menjadi sulit untuk ditentukan sosoknya. Kendati demikian, legitimasi sebagai penyair/ sastrawan telah melekat di dalam dirinya.

Nadjib berhasil menempatkan sastra sebagai sebuah produk budaya yang harus dimasyarakatkan. Kegiatannya sampai saat ini tetap mendayagunakan nilai-nilai yang ada dalam sastra. Tidak salah kiranya mengaitkan antara Nadjib dengan Jombang dan kesenian khas Jawa Timur Ludruk. Ludruk merupakan teater rakyat dengan ciri khas seluruh pemainnya adalah laki- 


\section{Jurnal Poetika Vol. III No. 2, Desember 2015}

laki. Oleh sebab itu, satu pemain Ludruk harus dapat memainkan berbagai karakter tokoh, baik laki-laki maupun perempuan, dalam setiap pementasannya. Begitulah Nadjib, dia adalah sastrawan yang berperan sebagai siapa saja dan apa saja di berbagai arena.

Modal yang dimiliki Nadjib digunakan dalam banyak trajektori sebagai disposisi untuk mengoperasikan penempatannya dan mendapat keuntungan sesuai dengan kesempatan yang ia miliki. Hal tersebut tidak dapat lepas dari kehidupan sastra yang terus dieksplorasi ke dalam berbagai praktik di masyarakat yang dikerjakannya. Posisi sosial Nadjib semakin langgeng berkat peran agen dalam pertarungan, dengan mengakumulasi dan mengelola modal simbolik yang diperoleh dalam arena. Kini nama Emha Ainun Nadjib menjadi lebih kokoh dibandingkan dengan karya-karyanya, baik dalam arena sastra maupun dalam arena sosial, di Indonesia maupun internasional.

\section{Kesimpulan}

Kesastrawanan Nadjib menempati posisi yang mapan dan mampu bertahan baik dalam arena sastra maupun arena sosial. Keberhasilan Nadjib pada posisi tersebut karena adanya dukungan dari agen di sekelilingnya serta banyaknya arena yang ia masuki. Dengan menggunakan strategi rekonvensi dan strategi reproduksi, Nadjib dapat meraih posisi yang kokoh di arena sastra dan arena sosial. Strategi rekonvensi dikerjakan Nadjib dengan memproduksi banyak karya dan konsep dalam arena sastra nasional. Untuk mengaplikasikan investasi ide-idenya itu, Nadjib menggunakan strategi reproduksi sebagai titik balik. Segenap aktivitas Nadjib senantiasa mendayagunakan sastra yang direproduksi sebagai alat komunikasi tegur-sapa budaya dalam arena sosial. Artinya, Nadjib senantiasa mendayagunakan sastra dalam meraih posisi di arena sastra hingga arena sosial. Banyaknya agen di sekeliling Nadjib terus-menerus melegitimasi Nadjib di arena sastra dan sosial. Keberadaan agen berhasil mengokohkan posisinya di setiap arena dan menjadikan modal yang dimiliki Nadjib semakin besar. Dalam dari itu, citra kesuksesan dan status sosial kesastrawanan Nadjib ditunjukkan dengan peraihan posisi dalam arena hingga saat ini secara dinamis dan memiliki beragam potensi untuk eksis. Usaha Nadjib membawa sastra ke berbagai arena sebagai produk populer dalam bidang hiburan membuat pertahanan dan peningkatan modalnya ke arah masa depan semakin kokoh. Posisi kesastrawanan Nadjib kelak akan abadi baik di arena sastra maupun arena sosial, baik di dalam negeri maupun di dunia internasional.

\section{Daftar Pustaka}

Alfian M., M. Alfan, Aprinus Salam, Wawan Susetya. 2001. Kitab Ketentraman Emba Ainun Nadjib. Jakarta: Republika dan Zaituna.

Ariadinata, Joni. 2014. "Emha Ainun Nadjib: Tafakur Orang Desa" dalam 33 Tokoh Sastra Indonesia Paling Berpengaruh. Jamal D. Rahman dkk. Jakarta: Kepustakaan Populer Gramedia.

Astika, I Made. 2013. Pergulatan Umbu Landu Paranggi dalam Arena Sastra di Bali: Tinjauan Sosiologi Pierre Bourdieu. Tesis. Fakultas Ilmu Budaya Universitas Gadjah Mada Yogyakarta.

Betts, Ian L. 2006. Jalan Sunyi Emha. Jakarta: Kompas.

Bourdieu, Pierre. 1984. Distinction a Social Critique of the Judgement of Taste. (Translated by Richard Nice). Cambridge, Massachusetts: Harvard University Press . 1990. In Other Words: Essays Towards a Reflexive Sociology. (Translated by Mattews Adamson) Stanford, California: Stanford University Press.

1996. The Rules of Art. (translated Susan Emanuel). USA: Stanford University Press.

2012. Arena Produksi Kultural: Sebuah Kajian Sosiologi Budaya. Bantul: Kreasi Wacana. 
Halim H.D. 1995. "Fenomena Emha". dalam Terus Mencoba Budaya Tanding. Emha Ainun Nadjib. Yogyakarta. Pustaka Pelajar.

Jabrohim. 2003. Tahajjud Cinta Emba Ainun Nadjib. Yogyakarta: Pustaka Pelajar bekerjasama dengan Pusat Aktifitas dan Studi Sastra Universitas Ahmad Dahlan Yogyakarta.

Johnson, Randal. 2012. "Pengantar Pierre Bourdieu tentang Seni, Sastra, dan Budaya" dalam Arena Produksi Kultural: Sebuah Kajian Sosiologi Budaya. Bantul: Kreasi Wacana.

Karnanta, Kukuh Yudha. 2013. 'Paradigma Teori Arena Produksi Kultural Sastra: Kajian Terhadap Pemikiran Pierre Bourdieu”. dalam Jurnal Ilmu Sastra Poetika volume I nomor 1, Juli 2013. Program Studi S2 Ilmu Sastra, FIB UGM. . 1995. Opini Plesetan: OPLeS. Bandung: Mizan.

. 2013. "Mengantarkan 1000 Puisi Boedi" dalam 1000 Puisi untuk Langit. Boedi Ismanto S.A. Jakarta: Kosa Kata Kita.

Pragolapati, Ragil Suwarna. 2002. Salam Penyair. Yogyakarta: Bentang.

Rahardjo, Toto, 2006. "Teman Siapa Saja” prolog dalam Jalan Sunyi Emha. Ian L. Betts. Jakarta: Kompas.

Santosa, Iman Budhi, Emha Ainun Nadjib, Mustofa W. Hasyim, Boedi Ismanto, Mahwi Air Tawar (ed). Orang-Orang Malioboro: Refleksi dan Pemaknaan Kiprah Persada Studi Klub 1969-1977 di Yogyakarta. (Naskah Praterbit)

Siregar, Ashadi. 2007. "Cermin Memantul" dalam Jalan Sunyi Emba. Ian L. Betts. Jakarta: Kompas. . 2007. "Pemaknaan Terhadap Dinamika Kreatif Yogyakarta Era '60-'70-an", dalam Orang-Orang Malioboro: Refleksi dan Pemaknaan Kiprah Persada Studi Klub 1969 -1977 di Yogyakarta. Iman Budhi
Santosa, Emha Ainun Nadjib, Mustofa W. Hasyim, Boedi Ismanto, Mahwi Air Tawar (ed). (Naskah Praterbit)

Teeuw, A. 1989. Sastra Indonesia Modern II. Jakarta: Pustaka Jaya

\section{Media Massa}

Betts, Ian L. "Sekelebatan Pandangan tentang Emha Ainun Nadjib" dalam SINDO, Minggu 24 Desember 2006.

Nadjib, Emha Ainun. 2012. "Presiden Malioboro: untuk Umbu" dalam Kompas, 16 Desember.

1991. "Kongres Kebudayaan Nasional IV, Kontroversi Dibalik Tampilnya Penyair Muda Nirwan Dewanto", Berita Buana, Jumat 1 November. 1983. "Dua Penyair Terkemuka Tolak Baca Puisi di TIM", Kedaulatan Rakyat, Rabu Kliwon, 26 Oktober.

\section{Website}

http:// www.library.ohiou.edu / indopubs/1996/01/01/0021.html In: Teks asli tulisan GM yang ditolak majalah Forum. (diakses 1 Juni 2014 pukul 11:27 WIB.) 